\title{
Article \\ DNA Methylation and Detoxification in the Earthworm Lumbricus terrestris Exposed to Cadmium and the DNA Demethylation Agent 5-aza-2'-deoxycytidine
}

\author{
Gerhard P. Aigner (D), Pamela Nenning, Birgit Fiechtner, Maja Šrut and Martina Höckner *(D)
}

Department of Zoology, Center for Molecular Biosciences Innsbruck, University of Innsbruck, Technikerstraße 25, 6020 Innsbruck, Austria; gerhard.p.aigner@uibk.ac.at (G.P.A.); pamela.nenning@student.uibk.ac.at (P.N.); birgit.fiechtner@uibk.ac.at (B.F.); Maja.Srut@uibk.ac.at (M.Š.)

* Correspondence: martina.hoeckner@uibk.ac.at

check for

updates

Citation: Aigner, G.P.; Nenning, P.; Fiechtner, B.; Šrut, M.; Höckner, M. DNA Methylation and Detoxification in the Earthworm Lumbricus terrestris Exposed to Cadmium and the DNA Demethylation Agent 5-aza-2' deoxycytidine. Toxics 2022, 10, 100. https://doi.org/10.3390/ toxics 10020100

Academic Editor: Juan C. SanchezHernandez

Received: 27 December 2021 Accepted: 18 February 2022 Published: 21 February 2022

Publisher's Note: MDPI stays neutral with regard to jurisdictional claims in published maps and institutional affiliations.

Copyright: (C) 2022 by the authors. Licensee MDPI, Basel, Switzerland. This article is an open access article distributed under the terms and conditions of the Creative Commons Attribution (CC BY) license (https:// creativecommons.org/licenses/by/ $4.0 /)$.

\begin{abstract}
Earthworms are well-established model organisms for testing the effects of heavy metal pollution. How DNA methylation affects cadmium (Cd) detoxification processes such as the expression of metallothionein 2 (MT2), however, is largely unknown. We therefore exposed Lumbricus terrestris to $200 \mathrm{mg}$ concentrations of Cd and 5-aza-2'-deoxycytidine (Aza), a demethylating agent, and sampled tissue and coelomocytes, cells of the innate immune system, for $48 \mathrm{~h}$. MT2 transcription significantly increased in the $\mathrm{Cd}$ - and Cd-Aza-treated groups. In tissue samples, a significant decrease in MT2 in the Aza-treated group was detected, showing that Aza treatment inhibits basal MT2 gene activity but has no effect on Cd-induced MT2 levels. Although Cd repressed the gene expression of DNA-(cytosine-5)-methyltransferase-1 (DNMT1), which is responsible for maintaining DNA methylation, DNMT activity was unchanged, meaning that methylation maintenance was not affected in coelomocytes. The treatment did not influence DNMT3, which mediates de novo methylation, TET gene expression, which orchestrates demethylation, and global levels of hydroxymethylcytosine $(5 \mathrm{hmC})$, a product of the demethylation process. Taken together, this study indicates that Aza inhibits basal gene activity, in contrast to Cd-induced MT2 gene expression, but does not affect global DNA methylation. We therefore conclude that $\mathrm{Cd}$ detoxification based on the induction of MT2 does not relate to DNA methylation changes.
\end{abstract}

Keywords: DNA methylation; earthworms; cadmium; epigenetics; metallothionein; DNMT; TET; demethylation; 5-aza-2'-deoxycytidine; decitabine

\section{Introduction}

Earthworms, as ecosystem engineers, are important organisms for soil formation because their activities have a tremendous impact on organic matter decomposition, nutrient cycles, bioturbation, aggregate formation, etc. [1]. Over the last few centuries, human activities have caused an accumulation of heavy metals in the environment [2]. The heavy metal cadmium $(\mathrm{Cd})$ is one of the main soil pollutants declared as a carcinogenic substance by the WHO [3]. Thus, a Cd-polluted environment threatens soil life, including earthworms. Due to the chemical and physical similarities of $\mathrm{Cd}$ to the trace elements zinc ( $\mathrm{Zn})$ and calcium (Ca), substitutions of these elements lead to toxic effects [4]. Metallothioneins (MTs) are cysteine-rich proteins capable of binding Cd [5]. Various ecotoxicological studies in plants, vertebrates and invertebrates have been performed explaining the toxic effects of $\mathrm{Cd}$ [6-10]. In the last few decades, increased research effort was put into deciphering epigenetic alterations caused by environmental stressors such as $\mathrm{Cd}$. An altered epigenome can, in turn, play a role in adaption to environmental changes by influencing the activity of beneficial genes [11-13]. In the most modern definition, epigenetics is deemed the study of changes in gene functions that are heritable at least from one generation of cells to the next and do not entail a change in DNA sequence [14]. The environment influences 
epigenetic markers; these modifications can last for a long time and can even be measured across generations [15]. Therefore, epigenetic parameters were suggested as biomarkers for reflecting recent and past pollution burdens [16-18].

DNA methylation is the first and best-described epigenetic mechanism and refers to a methyl group added to the fifth carbon of the DNA base cytosine $(5 \mathrm{mC})$ and most often takes place at C-G dinucleotide pairs (CpG) [19-21]. CpG is methylated by DNA (cytosine5)-methyltransferase 1 (DNMT1) or 3 (DNMT3), which catalyze the reaction that forms $5 \mathrm{mC}$ by transferring a methyl group from S-adenosyl methionine (SAM) to the unmodified cytosine base [22]. DNA is methylated by DNMT3 de novo [23]. DNMT1 passes the methylation pattern on from one generation of cells to the next, which thus is often referred to as the DNA methylation maintenance enzyme [24]. The $5 \mathrm{mC}$ is either passively or actively demethylated. Passive demethylation occurs when $5 \mathrm{mC}$ spontaneously deaminates to thymine [25] or when repressed DNMT1 or co-factor genes/enzymes lead to a replication-dependent loss of methylation patterns [26]. DNA is actively demethylated by a pathway including ten-eleven translocation (TET), thymine-DNA-glycosylase (TDG) and base excision repair (BER). TET enzymes iteratively oxidize $5 \mathrm{mC}$ to 5 -hydroxymethylcytosine (5hmC), 5hmC to 5-formylcytosine (5fC) and 5fC to 5-carboxylcytosine (5caC) [27]. Methylation-sensitive transcription factors affect the activity of methylated genes [28,29]. Thus, unfavorable DNA methylation patterning can lead to various diseases, such as cancer [30]. Demethylation agents such as 5-aza-2'-deoxycitidine (Aza), also known as decitabine, are used in medicine to treat hypermethylation-associated ailments against acute myeloid leukemia [31,32]. Aza is a chemical analog of cytidine and is also capable of demethylating genes in invertebrates [33-35]. The introduction of Aza to a cell leads to several cascades of chemical reactions that form Aza-triphosphate (Aza-TP), which is incorporated into DNA during the S-phase of the cell cycle instead of cytosine [31,36-38]. During DNA replication, hemi-methylated sites normally become methylated by DNMT1, but the carbon at the fifth position is replaced by a nitrogen in Aza-TP. Thus, DNMT1 cannot perform the methyl transfer and remains covalently bonded to the cytosine analog, leading to a passive, replication-dependent loss of DNA methylation [31,39,40].

Organisms show various epigenetic reactions to environmental stressors, which can further differ on the tissue level. For example, in the mussel Crassostrea gigas exposed to the herbicide diuron, no significant effects on global methylation levels were observed for whole-tissue DNA, in contrast to the digestive gland [41] and sperm [42]. In the crayfish Procambarus virginalis, genes involved in DNA methylation are differentially expressed in certain tissues and specific developmental stages [43]. In Lumbricus terrestris coelomocytes, environmentally relevant $\mathrm{Cd}$ concentrations induce long-lasting global DNA methylation changes [44]. Coelomocytes are cells of the innate immune system of earthworms and are specialized in stress response, including the expression of MTs [45]. Recently, it was revealed that $L$. terrestris possesses genes responsible for DNA methylation patterning, but those were not responsible for Cd-induced DNA hypermethylation [46]. It was suggested to further study the role of epigenetic biomarkers in ecotoxicology and expand this research field to a variety of organisms and ecosystems $[47,48]$. However, only few epigenetic studies in ecotoxicology have focused on invertebrates [18].

Therefore, the aim of this study was to check for mechanistic relationships of Cdinduced hypermethylation and MT-mediated Cd detoxification in L. terrestris by using high doses of Cd (200 mg Cd/kg soil) and the demethylating agent Aza. More specifically, this study aimed to answer the following questions: (1) Does the short-term exposure to high doses of $\mathrm{Cd}$ lead to changes in global DNA methylation patterns, and if so, can this change be related to the induction of MT2?; (2) Do increased levels of Cd affect gene activity of the DNA methylation machinery?; (3) Does Aza treatment decrease global DNA-methylation levels and/or does Aza affect MT2 gene expression in earthworms? 


\section{Materials and Methods}

\subsection{Experimental Setup and Sampling}

Lumbricus terrestris specimens and soil for acclimation (mixture of humus and peat) were ordered from Proinsects $\mathrm{GmbH}$ (Minden, Germany). For acclimation, earthworms were stored for 2 weeks in the soil at $70 \%$ soil humidity, $15{ }^{\circ} \mathrm{C}$ room temperature, a day-night cycle of $8 / 16 \mathrm{~h}$ and were fed once per week with horse manure. For the experimental setup, one earthworm was placed im a Petri dish filled with either $15 \mathrm{~mL}$ phosphate-buffered saline (PBS) (NaCl $137 \mathrm{mM}$; KCl $2.7 \mathrm{mM} ; \mathrm{KH}_{2} \mathrm{PO}_{4} 1.76 \mathrm{mM} ; \mathrm{Na}_{2} \mathrm{HPO}_{4} 10.1 \mathrm{mM}$ ), $15 \mathrm{~mL}$ PBS spiked with $200 \mu \mathrm{g} / \mathrm{mL} \mathrm{CdCl} 2$ (Merck, Darmstadt, Germany), 15 mL PBS containing $10 \mu \mathrm{M}$ Aza (Sigma Aldrich A3656, St. Louis, MO, USA), or $15 \mathrm{~mL}$ PBS including both $200 \mu \mathrm{g} / \mathrm{mL} \mathrm{CdCl}_{2}$ and $10 \mu \mathrm{M}$ Aza (CdA). Earthworms were then incubated for $48 \mathrm{~h}$ under dark conditions at $15{ }^{\circ} \mathrm{C}$. The numbers of replicates used for specific analyses is given within the figure legends in the results section.

After the treatment, worms were washed with PBS and placed in a new Petri dish containing $7 \mathrm{~mL}$ cold guaiacol glyceryl ether phosphate-buffered saline (GGE-PBS) on ice. For non-invasive coelomocyte extrusion, worms were stimulated with a $9 \mathrm{~V}$ electric current, resulting in the release of coelomocytes through their dorsal pores [49]. The whole GGE-PBS-cell suspension was transferred into a fresh tube and centrifuged at $4029 \mathrm{rcf}$ at $4{ }^{\circ} \mathrm{C}$ for $10 \mathrm{~min}$. The supernatant was discarded, and the cell pellet was resuspended in $1 \mathrm{~mL}$ PBS. The cell number was determined using a Countess ${ }^{\mathrm{TM}} 2$ FL Automated Cell Counter (Thermo Fisher Scientific, Waltham, MA, USA). Samples with a cell count above $7 \times 10^{5}$ cells $/ \mathrm{mL}$ were further processed and centrifuged at $1902 \mathrm{rcf}$ at $4{ }^{\circ} \mathrm{C}$ for $4 \mathrm{~min}$. The supernatant was discarded and the pellet was either flash-frozen in liquid nitrogen and stored at ${ }^{\mathrm{TM}} 80^{\circ} \mathrm{C}$ until further use or was directly processed for RNA extraction. Directly after coelomocyte extrusion, earthworm tissue samples were taken and stored in $1 \mathrm{~mL}$ absolute EtOH (Merck, Darmstadt, Germany) at $-20{ }^{\circ} \mathrm{C}$ for RNA extraction, or shockfrozen in liquid nitrogen and stored at $-80^{\circ} \mathrm{C}$ for protein and DNA extraction. The same tissue section was used for the respective analyses.

\subsection{RNA Extraction and cDNA Synthesis}

For RNA extraction, 1 mL TRI REAGENT ${ }^{\circledR}$ (Sigma Aldrich, St. Louis, MO, USA) was added to coelomocyte samples and cells were disrupted by pipetting up and down several times. Tissue samples that were previously frozen were homogenized using six RNase-free glass beads in $1 \mathrm{~mL}$ TRI REAGENT ${ }^{\circledR}$, applying the benchtop homogenizer FastPrep-24 ${ }^{\mathrm{TM}}$ 5G (MP Biomedicals, Santa Ana, CA, USA). Three cycles of $40 \mathrm{~s}$ at $6 \mathrm{~m} / \mathrm{s}$ with a break of 2 min between each cycle were used for tissue disruption. RNA was extracted following the manufacturer's instructions. DNA was digested using DNAse I (Thermo Fisher Scientific, Waltham, MA, USA), including RiboLock (Thermo Fisher Scientific, Waltham, MA, USA) as an RNAse inhibitor. The quality of extracted RNA was evaluated by gel electrophoresis, assessing rRNA band integrity. The RNA concentration was measured in triplicate, using the Quant-iT ${ }^{\mathrm{TM}}$ RiboGreen ${ }^{\mathrm{TM}}$ RNA Assay Kit (Thermo Fisher Scientific, Waltham, MA, USA) on the plate reader Victor X4 (Perkin Elmer, Waltham, MA, USA). Subsequently, $450 \mathrm{ng}$ of total RNA was used for reverse transcription using RevertAid ${ }^{\mathrm{TM}} \mathrm{H}$ Minus Reverse Transcriptase (Thermo Fisher Scientific, Waltham, MA, USA), Random Hexamer Primers (Thermo Fisher Scientific, Waltham, MA, USA), and RiboLock (Thermo Fisher Scientific, Waltham, MA, USA), according to the user manual. To eliminate possible contamination with humic acid, an additional washing step was performed using the RNeasy ${ }^{\circledR}$ MinElute ${ }^{\circledR}$ Cleanup Kit (QIAGEN, Hilden, Germany), according to the manufacturer's instructions.

\subsection{Quantitative Real-Time PCR}

Absolute quantification using a standard curve prepared from a series of dilutions of known template concentrations and a primer matrix was applied to determine optimal primer concentrations. Copy numbers were measured on a QuantStudio ${ }^{\mathrm{TM}} 3$ RealTime PCR system (Thermo Fisher Scientific, Waltham, MA, USA) using previously pub- 
lished primers [46]: $5 \mu \mathrm{L}$ Power SYBR ${ }^{\mathrm{TM}}$ Green PCR-Master-Mix (Thermo Fisher Scientific, Waltham, MA USA) was used per sample. DNMT1 and DNMT3 were amplified as follows: $1 \mu \mathrm{L} 10 \times \mathrm{BSA}, 1 \mu \mathrm{L}$ forward primer $(9 \mu \mathrm{M}), 1 \mu \mathrm{L}$ reverse primer $(9 \mu \mathrm{M}), 1 \mu \mathrm{L}$ distilled water and $1 \mu \mathrm{L}$ cDNA. TET was amplified by adding $1 \mu \mathrm{L} 10 \times \mathrm{BSA}, 1 \mu \mathrm{L}$ forward primer $(3 \mu \mathrm{M}), 1 \mu \mathrm{L}$ reverse primer $(3 \mu \mathrm{M})$, and $2 \mu \mathrm{L}$ cDNA. For MT2, $1 \mu \mathrm{L} 10 \times \mathrm{BSA}, 1 \mu \mathrm{L}$ forward primer $(9 \mu \mathrm{M}), 1 \mu \mathrm{L}$ reverse primer $(9 \mu \mathrm{M})$, and $2 \mu \mathrm{L}$ cDNA. The following conditions were applied: $50{ }^{\circ} \mathrm{C}$ for $2 \mathrm{~min} ; 95^{\circ} \mathrm{C}$ for $10 \mathrm{~min} ; 40$ repeats of $95^{\circ} \mathrm{C}$ for $15 \mathrm{~s}$ and $60{ }^{\circ} \mathrm{C}$ for $1 \mathrm{~min}$. Three technical replicates were generated for each sample. According to the standard curve, absolute copy numbers per 100 ng RNA were determined. To compare different plates, values were normalized to the threshold. Values that were below the detection range of our standard curve were set to zero.

\subsection{Protein Extraction and DNMT Activity}

The extraction of coelomocyte proteins was performed as previously described for aphids [50]: $100 \mu \mathrm{L}$ proteinase inhibitor buffer $\left(150 \mathrm{mM} \mathrm{NaCl}, 50 \mathrm{mM} \mathrm{Na}_{2} \mathrm{HPO}_{4}, 50 \mathrm{mM}\right.$ $\left.\mathrm{NaHPO}_{4}, \mathrm{pH} 7.5\right), 10 \mu \mathrm{L}$ PMSF $(1 \mathrm{mM})$ and $10 \mu \mathrm{L}$ DTT $(1 \mathrm{mM})$ were added to frozen coelomocyte samples and a micro pestle was used to homogenize the cells. Homogenates were centrifuged at $21,130 \mathrm{rcf}$ at $4{ }^{\circ} \mathrm{C}$ for $10 \mathrm{~min}$, and the supernatant containing the nuclear fraction was transferred to a clean tube. The protein concentration was measured using a NanoDrop ${ }^{\mathrm{TM}} 2000$ (Thermo Fisher Scientific, Waltham, MA, USA). The protein activity of DNMT was quantified using the colorimetric DNMT Activity Quantification Kit (ab113467, Abcam, Cambridge, UK) by following the user manual for nuclear fractions.

\subsection{Quantification of 5-Methylcytosine (5mC) and 5-Hydroxymethylcytosine (5hmC)}

Genomic DNA methylation levels were determined from the same individuals that were also used for quantitative real-time PCR. Genomic DNA of tissue samples was extracted using the GenElute ${ }^{\mathrm{TM}}$ Mammalian Genomic DNA Mini-prep Kit (Sigma-Aldrich, St. Louis, MO, USA) according to the manufacturer's instructions: $25 \mathrm{mg}$ samples of frozen tissue were homogenized using Lysis Solution $\mathrm{T}$ and Proteinase $\mathrm{K}$ at $55{ }^{\circ} \mathrm{C}$ for $4 \mathrm{~h}$, and DNA was stored at $4{ }^{\circ} \mathrm{C}$. DNA extraction from coelomocytes was performed using TRI REAGENT ${ }^{\circledR}$ (Sigma Aldrich, St. Louis, MO, USA), following the manufacturer's instructions for DNA isolation. The quality and quantity of DNA were determined on a NanoDrop ${ }^{\mathrm{TM}} 2000$ spectrophotometer (Thermo Fisher Scientific, Waltham, MA, USA). DNA was diluted to a concentration of $12.5 \mathrm{ng} / \mu \mathrm{L}$ using DMPC water. Then, $2 \mu \mathrm{L}$ of diluted DNA solution was mixed with $2 \mu \mathrm{L} 2 \times$ DNA denaturation buffer $(200 \mathrm{mM} \mathrm{NaOH}, 20 \mathrm{mM}$ EDTA) and incubated at $95^{\circ} \mathrm{C}$ for $10 \mathrm{~min}$. Samples were placed on ice to cool and then centrifuged briefly. Subsequently, $4 \mu \mathrm{L} 20 \times$ saline sodium citrate buffer (SSC: $3 \mathrm{M} \mathrm{NaCl}$, $0.3 \mathrm{M}$ sodium citrate, $\mathrm{pH} 7.0$ ) was added to each sample and kept on ice.

Hybond $^{\mathrm{TM}}$ P $0.45 \mu \mathrm{m}$ PVDF membranes (Thermo Fisher Scientific, Waltham, MA, USA) were used for dot blot analysis. Per sample, a minimum of $1 \mathrm{~cm}^{2}$ was marked carefully using a sharp pencil and a ruler. The handling of membranes was performed exclusively with forceps. The membrane was activated using 100\% methanol for a few seconds and washed with $1 \times$ Tris-buffered saline containing TWEEN ${ }^{\circledR} 20$ (TBS-T: $137 \mathrm{mM}$ $\mathrm{NaCl}, 20 \mathrm{mM}$ Tris HCl, pH $=7.6$ and $1.23 \mathrm{M}$ Tween ${ }^{\circledR} 20$ (Carl Roth GmbH \& Co. KG, Karlsruhe, Germany)). The membrane was left for $3 \mathrm{~min}$ at room temperature placed on TBS-T-soaked blotting paper. Then, $8 \mu \mathrm{L}$ per sample ( $25 \mathrm{ng}$ total DNA and buffers) was applied to the designated areas on the membrane. The membrane was left at room temperature until all dots were completely absorbed and then cross-linked with UV light for 3 min using the ChemiDoc ${ }^{\mathrm{TM}}$ MP Imaging System (Bio-Rad Laboratories, Hercules, CA, USA). Pure $(100 \%)$ methanol was used for a few seconds to reactivate the membrane followed by a washing step with TBS-T. For blocking, $10 \mathrm{~mL}$ TBS-T including $5 \%$ dissolved BSA (Albumin Fraction V, Carl Roth GmbH \& Co. KG, Karlsruhe, Germany) was applied for $1 \mathrm{~h}$ at room temperature on a shaker. Then, the membrane was incubated with the mouse monoclonal anti-5mC antibody (SAB2702243, Sigma-Aldrich, St. Louis, MO, USA), 
which was diluted 1:1000 in $10 \mathrm{~mL}$ TBS-T with $5 \%$ BSA at $4{ }^{\circ} \mathrm{C}$ on a shaker for $24 \mathrm{~h}$. The membrane was washed three times with TBS-T for $10 \mathrm{~min}$ and incubated with the goat anti-mouse IgG labelled with horseradish peroxidase (A3562, Sigma-Aldrich, St. Louis, MO, USA) (1:10,000 in TBS-T with 5\% BSA) for $1 \mathrm{~h}$ at room temperature on a shaker followed by three further washing steps using TBS-T for $10 \mathrm{~min}$.

The same procedure was applied for detecting $5 \mathrm{hmC}$, with the following modification: $500 \mathrm{ng}$ of total DNA was used per dot. Blocking and antibody incubation were performed with TBS-T including 5\% milk powder. The membrane was incubated with anti-5hmC antibody (THP39770, THP Medical Products, Vienna, Austria) at a concentration of 1:10,000. For detection, the rabbit anti-mouse antibody (ab6421, Abcam, Cambridge, UK) was used at a concentration of 1:10,000.

Detection was conducted using ECL Select ${ }^{\mathrm{TM}}$ Western Blotting Detection Reagents (Thermo Fisher Scientific, Waltham, MA, USA) on the ChemiDoc ${ }^{\mathrm{TM}} \mathrm{MP}$ Imaging System (Bio-Rad Laboratories, Hercules, CA, USA). Subsequently, the $1 \mathrm{~mL}$ peroxide solution and $1 \mathrm{~mL}$ luminol solution was mixed and applied to the membrane and incubated for $2 \mathrm{~min}$ at room temperature. The excessive fluid was removed and chemiluminescence was detected with an exposure time of $0.5 \mathrm{~s}$. Image-Lab 4.1 (Bio-Rad Laboratories, Hercules, CA, USA) was applied to quantify the dots relative to the controls, and the backgroundadjusted volume was used for signal detection. Analysis settings were the local background subtraction method for volume and the linear quantity regression method for the analysis.

\subsection{Statistical Analysis}

Statistical analyses was performed with GraphPad Prism 8.3 software (GraphPad Software, San Diego, CA, USA). Outliers were calculated using the Grubbs test and were considered significant at $p<0.01$. Outliers were excluded from further analysis. Normality distributions were calculated using the Kolmogorov-Smirnov test if possible. Otherwise, the Shapiro-Wilk test was used to identify data distribution. Normally distributed data were analyzed by performing Student's $t$-tests. If $\mathrm{f}$-tests revealed significant differences in variance $(p<0.05)$ Welch's correction was performed. Non-normally distributed data were analyzed using the Mann-Whitney U test.

Multidimensional scaling analysis (MDS) and correlation tests were performed using RStudio Version 1.3.1073 [51]. MDS was performed using the script "cmdscale". The analyzed variables of tissue and coelomocyte samples were DNMT1, TET, MT2 and 5mC. The number of samples used for the analysis was as follows: $C=5$ and $7 ; A=6$ and 5; $\mathrm{Cd}=5$ and 8; $\mathrm{CdA}=3$ and 13 for coelomocytes and tissue, respectively. The script "ordiellipse" (package "vegan" [52]) was used to generate an ellipse around treatment groups (confidence of 90\%). ANOVA and Tukey's HSD tests on MDS score values $(p<0.05)$ revealed a significant difference between treatment groups in the first two dimensions.

\section{Results}

\subsection{Quantification of Gene Expression}

In general, across all treatments, gene expression levels of MT2, DNMT1 and TET were significantly higher in coelomocytes compared with tissue samples. Significance levels are presented in Table 1. 
Table 1. $p$-values and statistical tests applied to identify differences in gene activity within treatment groups between coelomocytes and tissue.

\begin{tabular}{cccc}
\hline Gene & Treatment & Statistical Test & $p$ Value \\
\hline \multirow{3}{*}{ MT2 } & C & Student's -test & 0.0117 \\
& $\mathrm{~A}$ & Mann-Whitney U test & 0.0606 \\
& $\mathrm{Cd}$ & Welch's test & 0.0324 \\
& $\mathrm{CdA}$ & Student's $t$-test & $<0.0001$ \\
\hline \multirow{2}{*}{ DNMT1 } & $\mathrm{C}$ & Welch's test & 0.0216 \\
& $\mathrm{~A}$ & Welch's test & 0.019 \\
& $\mathrm{Cd}$ & Mann-Whitney U test & 0.0455 \\
& $\mathrm{CdA}$ & Welch's test & 0.2101 \\
\hline & $\mathrm{C}$ & Welch's test & 0.0025 \\
$\mathrm{TET}$ & $\mathrm{A}$ & Student's $t$-test & 0.0208 \\
& $\mathrm{Cd}$ & Welch's test & 0.0025 \\
& $\mathrm{CdA}$ & Student's $t$-test & 0.0008 \\
\hline
\end{tabular}

In coelomocytes, MT2 gene expression was significantly increased after $48 \mathrm{~h}$ of exposure in Cd- (Welch's test, $p<0.05$ ) and CdA-treated groups (Welch's test, $p<0.05$ ) in comparison to the control (Figure 1A). For tissue, MT2 expression levels significantly increased in Cd (Welch's test, $p<0.01$ ) and CdA (Welch's test, $p<0.01$ ) exposed groups in comparison to the control, whereas the treatment with Aza inhibited MT2 transcription (Mann-Whitney U test, $p<0.05$ ) (Figure 1B).

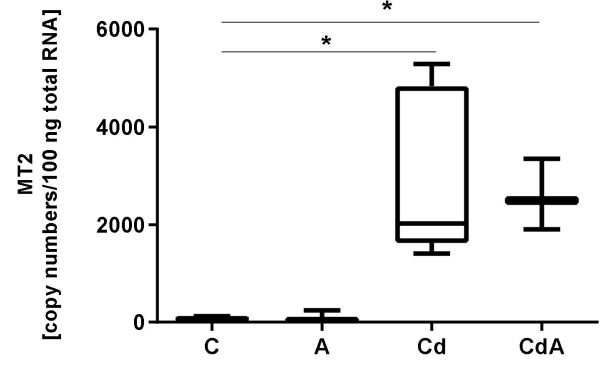

(a)

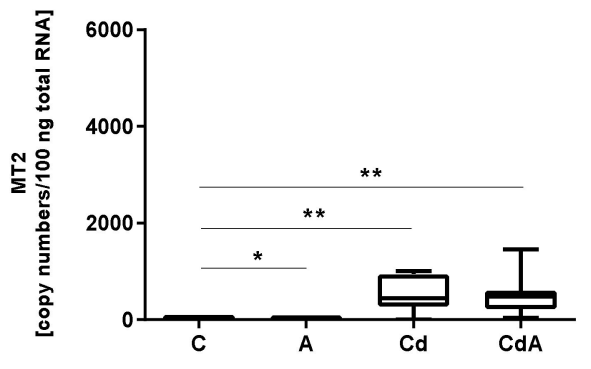

(b)

Figure 1. (a) mRNA copy numbers of Metallothionein 2 (MT2) in L. terrestris coelomocytes and (b) tissue of control (C) and exposed individuals (5-aza-2'-deoxycytidine (A); $200 \mathrm{mg} / \mathrm{kg} \mathrm{CdCl} 2$ (Cd); 5-aza-2'-deoxycytidine and $\left.200 \mathrm{mg} / \mathrm{kg} \mathrm{CdCl}_{2}(\mathrm{CdA})\right)$. Stars indicate significant differences between treatments and the control $\left(p<0.05\left(^{*}\right) ; p<0.01\left(^{* *}\right)\right.$ ). Replicates per treatment analyzed in coelomocytes: $\mathrm{C}=5, \mathrm{~A}=6, \mathrm{Cd}=5, \mathrm{CdA}=3$. Replicates per treatment analyzed in tissue: $\mathrm{C}=7, \mathrm{~A}=5$, $\mathrm{Cd}=8, \mathrm{CdA}=12$.

DNMT1 gene expression significantly decreased in coelomocytes in the Cd-exposed group in comparison to the control (Welch's test, $p<0.05$ ). Neither for tissue, nor for coelomocytes, were significant differences in TET gene activity observed (Figure 2). Gene expression levels of DNMT3 showed very low constitutive transcription rates for both tissue and coelomocytes (data not shown). 
Coelomocytes

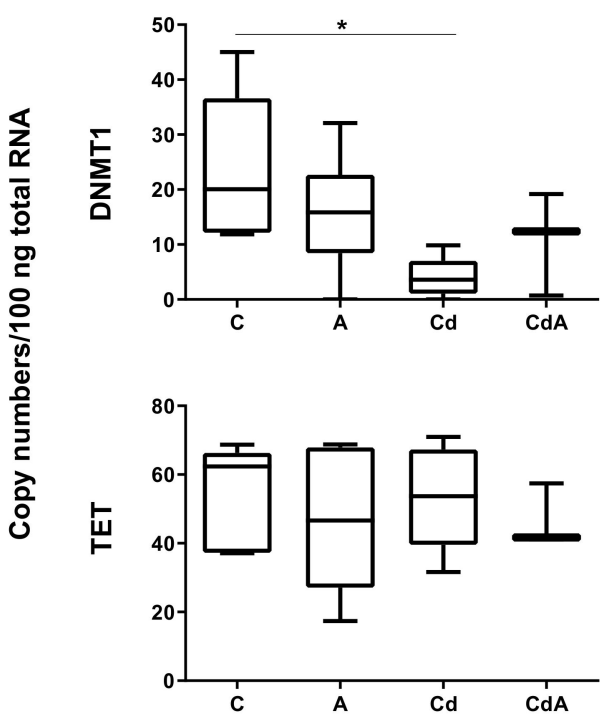

Tissue
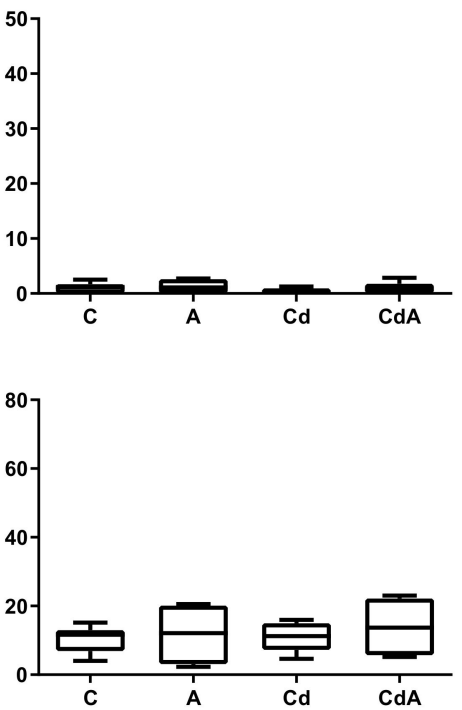

Figure 2. mRNA copy numbers of DNA-methyltransferase 1 (DNMT1) and ten-eleven translocation (TET) in L. terrestris coelomocytes and tissue of control (C) and exposed individuals (5-aza- $2^{\prime}$ deoxycytidine (A); $200 \mathrm{mg} / \mathrm{kg} \mathrm{CdCl}_{2}$ (Cd); 5-aza-2'-deoxycytidine and $200 \mathrm{mg} / \mathrm{kg} \mathrm{CdCl}$ (CdA)). Stars indicate significant differences between treatments and control $\left.\left(p<0.05{ }^{*}\right)\right)$. Replicates per treatment analyzed in coelomocytes: $C=5, A=6, C d=5, C d A=3$. Replicates per treatment analyzed in tissue: $\mathrm{C}=6, \mathrm{~A}=4, \mathrm{Cd}=6, \mathrm{CdA}=6$.

\subsection{Global Methylation Level and DNMT Activity}

Global DNA methylation levels of cytosines in tissue samples did not differ significantly (Supplementary Figure S1A). In coelomocytes, a slight, but not significant decrease was detected in the CdA-treated group in comparison to the control (Figure 3a). DNMT activity of earthworm coelomocytes did not significantly differ between the control and Cd-treated group (Figure 3b).

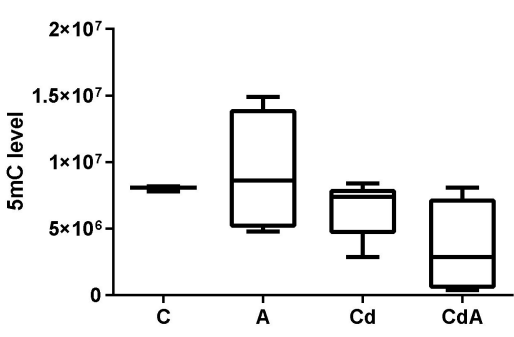

(a)

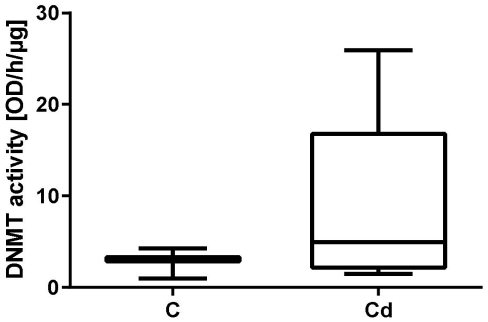

(b)

Figure 3. (a) Global DNA methylation levels in coelomocytes extruded from control $(\mathrm{C}, n=4)$ and exposed L. terrestris specimens (5-aza-2'-deoxycytidine (A), $n=4 ; 200 \mathrm{mg} / \mathrm{kg} \mathrm{Cd}(\mathrm{Cd}) n=5 ; 5$-aza-2' deoxycytidine and $\left.200 \mathrm{mg} / \mathrm{kg} \mathrm{CdCl}_{2}(\mathrm{CdA}), n=4\right)$ after $48 \mathrm{~h}$ of exposure. (b) Total DNMT protein activity (DNMT1 and DNMT3) of coelomocytes extruded from control (C, $n=3)$ and Cd-exposed $\left(200 \mathrm{mg} / \mathrm{kg} \mathrm{CdCl}_{2}(\mathrm{Cd}, n=6)\right)$ L. terrestris individuals after $48 \mathrm{~h}$ of exposure.

\subsection{Global 5hmc}

$\mathrm{Cd}$ had no significant influence on global 5hmC levels in DNA extracted from coelomocytes (Supplementary Figure S1B). 


\subsection{Multidimensional Scaling}

For tissue samples, MDS analysis revealed significant differences between groups in the second dimension. $\mathrm{Cd}$ and $\mathrm{CdA}$ groups were significantly different from $\mathrm{C}(p=0.0043241$ and 0.0006196 , respectively) and CdA was significantly different from A ( $p=0.0152221)$ (Figure 4a).

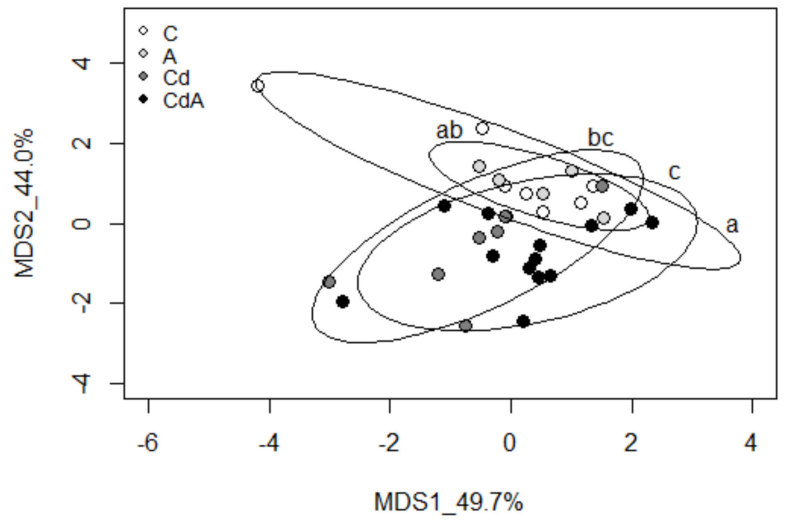

(a)

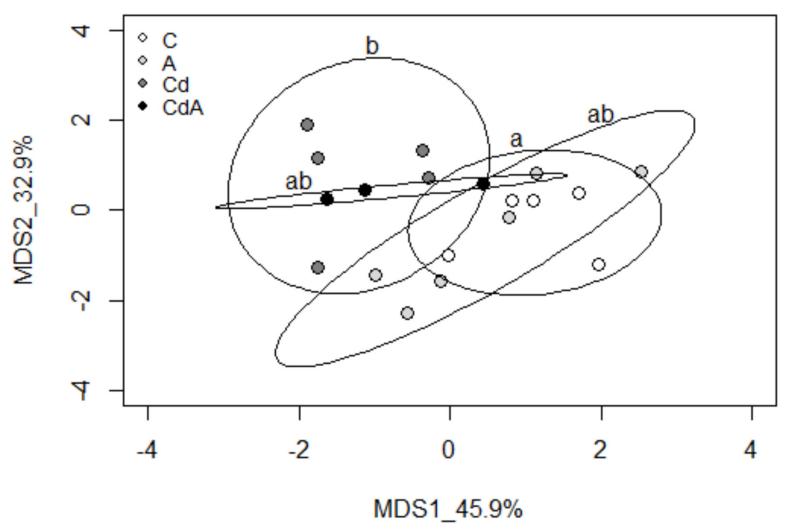

(b)

Figure 4. (a) MDS analysis using tissue samples and variables DNMT1, TET, MT2 and 5mC. Significance in group separation is based on the MDS2 dimension (shown by letters). The ellipse around the treatment groups indicates a confidence of $90 \%$. (b) MDS analysis using coelomocyte samples and variables DNMT1, TET, MT2 and 5mC. Significance in group separation is based on the MDS1 dimension (shown by letters). The ellipse around treatment groups indicates a confidence of $90 \%$.

For coelomocyte samples, MDS revealed a significant difference between $\mathrm{C}$ and $\mathrm{Cd}$ groups in the first dimension ( $p=0.0127395)$ (Figure $4 b)$.

\section{Discussion}

We tested the effects of the heavy metal $\mathrm{Cd}$ and the demethylation agent Aza in the earthworm Lumbricus terrestris with a special focus on MT2-related Cd detoxification, changes in global $5 \mathrm{mC}$ and $5 \mathrm{hmC}$ levels, and the activity of DNA methylation-associated genes in coelomocytes and tissue samples.

Multidimensional scaling clearly revealed similar separation between treatment groups for both tissue and coelomocyte samples. For tissue samples, $\mathrm{Cd}$ and $\mathrm{CdA}$ showed difference from the control group; however, because Aza treatment did not differ from the control, we conclude that the effects were Cd-related. A similar trend was evident for coelomocyte samples; however, only the Cd group differed significantly from the control.

Compared with tissue samples, gene expression in coelomocytes was higher across all treatments. Increased MT2 levels in coelomocytes might be due to their specialized function in Cd detoxification [45]. DNMT tissue-specific expression and altered expression in response to different types of stress has been demonstrated previously [53]. Another study on DNA methylation genes revealed that DNMT as well as TET are expressed differentially in tissues and during development [54]. Herein, we confirmed a tissuespecific expression of DNMT1 as well as TET in earthworms and propose that DNA methylation takes over specialized functions in coelomocytes.

Astonishingly Aza inhibited MT2 gene expression, which was not observed in the presence of $\mathrm{Cd}$, indicating that Aza affects basal gene activity, but not Cd-inducible MT2 transcription in L. terrestris tissue. Interestingly, the opposite effect was described in vertebrates. In rat liver cells, Aza treatment led to a dose-dependent increase in MT expression and to hypomethylation of the MT gene, which was suggested to play a role in enhanced expression rates [55]. 
Aza inhibits DNMT1 and requires the cells to divide in order to demethylate their genes [37]. In our study, Aza treatment did not influence global DNA methylation levels. Therefore, either the used concentrations were too low, Aza could not bind to L. terrestris DNMT1 protein, or the treatment time was too short for Aza to take effect. Aza treatment in invertebrate species showed different effects on DNA methylation patterns. One study investigated the effects of an endoparasitoid wasp on DNA methylation patterns and altered gene expression in its host species, the moth Plutella xylostella. As part of this study, Aza was injected into moth larvae, leading to a dose-dependent decrease in $5 \mathrm{mC}$ intensity $48 \mathrm{~h}$ post-injection [33]. In 2-3-day-old silkworm Bombyx mori pupa, Aza led to a decrease in DNA methylation at specific CpG sites in wing-specific genes [34]. In callow Bombus terrestris bumblebee workers, Aza treatment led to changes in DNA methylation patterns, but the treatment had no effect on adult workers. Regarding DNA methylation pattern changes, Aza treatment induced hypo- as well as hypermethylation changes in several of the observed loci in callow workers. The authors hypothesized that a weak proliferation rate in adult bees could explain their unchanged methylation pattern, because Aza requires the cells to divide in order to fulfill its potential as a demethylating agent [56]. We also performed our experiment in adults and observed that Aza did not demethylate DNA on a global level. Weak proliferation rates could explain unchanged DNA methylation patterns, especially in earthworm coelomocytes, which are known to have weak proliferation rates, as previously shown in Dendrobaena veneta [57]. In adult female Nasonia vitripennis wasps, Aza treatment led to both hypo- and hypermethylation and strongly depended on the exposure period, tissue type and collection time [58]. Recently, a study in the marine annelid Platynereis dumerilii showed that treatment with $50 \mu \mathrm{M}$ AZA $24-72 \mathrm{~h}$ post-fertilization led to a decrease in global DNA methylation, morphological deformations and increased mortality. All treated larvae died within 10 days post fertilization [35]. Since $48 \mathrm{~h}$ of $50 \mu \mathrm{M}$ Aza treatment led to $100 \%$ mortality in earthworms, we used $10 \mu \mathrm{M}$ Aza for earthworm exposures.

In murine HT22 cells, Aza treatment caused alterations of the cell cycle leading to S-phase arrest, and low doses of Aza significantly reduced DNMT1 gene and protein expression as well as DNMT1 protein activity. Interestingly, this decrease was not observed for total DNMT activity when DNMT3 proteins were included [59]. In our study, Aza had no effect on DNMT1 gene expression, but an Aza-mediated S-phase arrest could explain unchanged global DNA methylation patterns in L. terrestris. For a better application of demethylation agents in experimental biology, further studies that test the demethylation potential of several reagents in invertebrate species are needed.

In a recently published study on earthworms exposed to environmentally relevant $\mathrm{Cd}$ concentrations, changes in global DNA methylation were observed after 2 weeks, and the authors did not observe differences in gene expression for DNMT1, DNMT3 and TET genes at all examined time points [46]. Compared with the latter, in the present study, higher doses of $\mathrm{Cd}$ were used, but still no effect on the activity of the TET gene and global $5 \mathrm{hmC}$ levels were observed, indicating that TET protein activity was not affected. We observed very low constitutive transcription rates of DNMT3 in tissue and coelomocytes. Thus, even higher doses of Cd did not show an effect on TET and DNMT3 gene activity. The decrease in DNMT1 gene expression in coelomocytes had no effect on DNMT activity, which could be a reason for unchanged DNA methylation. DNMT1 is known to be post-translationally modified. Therefore, we assumed that a down-regulation of DNMT1 gene expression in earthworms would not necessarily and immediately lead to a change in protein activity. It has further been shown that DNMT gene expression does not reflect global methylation levels $[60,61]$.

Impaired upstream signaling could be a possible explanation for the Cd-induced repressed transcription of DNMT1. Zn and Cd are chemically and physically similar, enabling substitution of these elements, which is known to destabilize proteins containing zinc finger domains $[62,63]$, for example, and consequently affecting the DNA binding affinity [64]. Zinc finger proteins such as GLI1, SP1, SP3, and ZCCHC6 have previously been 
shown to be involved in DNMT gene regulation [65-68]. Cd-incorporated Zn finger proteins could explain the toxic effects of $\mathrm{Cd}$, leading to the decrease in DNMT1 gene activity.

Earthworms were shown to develop an acclimation mechanism when exposed to low doses of $\mathrm{Cd}$; $\mathrm{Cd}$ exposure leads to global DNA hypermethylation [44]. We hypothesized that these $\mathrm{Cd}$-induced epigenetic changes could explain the enhanced MT2-related detoxification mechanisms, but in L. terrestris, MT2 gene expression could not be correlated to changes in MT2 gene body methylation patterns [46]. In the present work, we observed significantly upregulated MT2 transcription in Cd-exposed groups in tissue and coelomocytes. No changes in global DNA methylation levels occurred; therefore, we suggest that $\mathrm{Cd}$ detoxification is not related to global DNA methylation changes, at least not regarding the methylation of cytosines.

We know that in L. terrestris exposed to low doses of $\mathrm{Cd}$, hypermethylation is observed after 4 weeks of exposure in coelomocytes and after 2 weeks in tissue [44,46]. Interestingly, high doses of $\mathrm{Cd}$ did not change global DNA methylation in our study, neither for coelomocytes nor for tissue after $48 \mathrm{~h}$. In the brine shrimp Artemia franciscana, global DNA methylation did not change after two days of $\mathrm{Cd}$ exposure [69]. Thus, a change in Cd-induced global DNA methylation strongly depends on the dose and exposure time.

\section{Conclusions}

The results of this study indicate that in earthworm coelomocytes, high doses of $\mathrm{Cd}$ repress the gene expression of DNMT1, which is responsible for maintaining DNA methylation. However, downregulated DNMT1 had no effect on total DNMT protein activity and on global DNA methylation levels. Interestingly, Aza also had no effect on global methylation, but inhibited basal MT2 gene expression in L. terrestris tissue. However, MT2 transcription was significantly upregulated in Cd- and CdA-treated groups, meaning that DNA methylation changes and Aza treatment do not affect the induction MT2.

Supplementary Materials: The following supporting information can be downloaded at: https: //www.mdpi.com/article/10.3390/toxics10020100/s1, Figure S1: Global 5mC in tissue and 5hmC in coelomocytes.

Author Contributions: Conceptualization, M.H.; methodology, G.P.A., P.N., M.Š. and M.H.; validation, M.Š. and M.H.; formal analysis, G.P.A., P.N., M.Š. and M.H.; investigation, G.P.A., M.Š. and M.H.; resources, M.Š. and M.H.; data curation, G.P.A., P.N. and B.F.; writing-original draft, G.P.A.; writing—review and editing, G.P.A., M.Š. and M.H.; visualization, G.P.A., M.Š. and M.H.; supervision, M.H.; project administration, M.H; funding acquisition, M.Š. and M.H. All authors have read and agreed to the published version of the manuscript.

Funding: This research was funded by the AUSTRIAN SCIENCE FUND (FWF), grant numbers FM022620 and P33835-B.

Institutional Review Board Statement: Not applicable.

Informed Consent Statement: Not applicable.

Data Availability Statement: Data is contained within the article or supplementary material.

Acknowledgments: The authors thank Veronika Niedrist for performing dot blots and her support during sampling.

Conflicts of Interest: The authors declare no conflict of interest.

\section{References}

1. Lemtiri, A.; Colinet, G.; Alabi, T.; Cluzeau, D.; Zirbes, L.; Haubruge, É.; Francis, F. Impacts of Earthworms on Soil Components and Dynamics. A Review. 2014. Available online: https://popups.uliege.be/1780-4507/index.php?id=10881 (accessed on 18 June 2021).

2. Wuana, R.A.; Okieimen, F.E. Heavy Metals in Contaminated Soils: A Review of Sources, Chemistry, Risks and Best Available Strategies for Remediation. Int. Sch. Res. Not. 2011, 2011, 402647. [CrossRef] 
3. Asami, T. Pollution of Soils by Cadmium. In Changing Metal Cycles and Human Health; Springer: Berlin/Heidelberg, Germany, 1984; pp. 95-111.

4. Bridges, C.C.; Zalups, R.K. Molecular and ionic mimicry and the transport of toxic metals. Toxicol. Appl. Pharmacol. 2005, 204, 274-308. [CrossRef]

5. Duncan, K. Metallothioneins and Related Chelators. Metal Ions in Life Sciences Vol. 5. Edited by Astrid Sigel, Helmut Sigel and Roland, K.O. Sigel. Angew. Chem. Int. Ed. 2009, 48, 7966-7967. [CrossRef]

6. Ma, Y.; Rivera-Ingraham, G.A.; Nommick, A.; Bickmeyer, U.; Roeder, T. Copper and cadmium administration induce toxicity and oxidative stress in the marine flatworm Macrostomum lignano. Aquat. Toxicol. 2020, 221, 105428. [CrossRef] [PubMed]

7. Haider, F.U.; Liqun, C.; Coulter, J.A.; Cheema, S.A.; Wu, J.; Zhang, R.; Wenjun, M.; Farooq, M. Cadmium toxicity in plants: Impacts and remediation strategies. Ecotoxicol. Environ. Saf. 2021, 211, 111887. [CrossRef] [PubMed]

8. Pedrini-Martha, V.; Schnegg, R.; Schäfer, G.G.; Lieb, B.; Salvenmoser, W.; Dallinger, R. Responsiveness of metallothionein and hemocyanin genes to cadmium and copper exposure in the garden snail Cornu aspersum. J. Exp. Zool. Part A Ecol. Integr. Physiol. 2020, 335, 228-238. [CrossRef]

9. Tang, S.; Allagadda, V.; Chibli, H.; Nadeau, J.L.; Mayer, G.D. Comparison of cytotoxicity and expression of metal regulatory genes in zebrafish (Danio rerio) liver cells exposed to cadmium sulfate, zinc sulfate and quantum dots. Metallomics 2013, 5, 1411-1422. [CrossRef]

10. Probst, G.S.; Bousquet, W.F.; Miya, T.S. Correlation of hepatic metallothionein concentrations with acute cadmium toxicity in the mouse. Toxicol. Appl. Pharmacol. 1977, 39, 61-69. [CrossRef]

11. Baccarelli, A.; Bollati, V. Epigenetics and environmental chemicals. Curr. Opin. Pediatr. 2009, 21, 243-251. [CrossRef]

12. Flores, K.B.; Wolschin, F.; Amdam, G.V. The Role of Methylation of DNA in Environmental Adaptation. Integr. Comp. Biol. 2013, 53, 359-372. [CrossRef]

13. Martinez-Zamudio, R.; Ha, H.C. Environmental epigenetics in metal exposure. Epigenetics 2011, 6, 820-827. [CrossRef] [PubMed]

14. Dupont, C.; Armant, D.R.; Brenner, C.A. Epigenetics: Definition, Mechanisms and Clinical Perspective. Semin. Reprod. Med. 2009, 27, 351-357. [CrossRef] [PubMed]

15. Trijau, M.; Asselman, J.; Armant, O.; Adam-Guillermin, C.; De Schamphelaere, K.A.C.; Alonzo, F. Transgenerational DNA Methylation Changes in Daphnia magna Exposed to Chronic $\gamma$ Irradiation. Environ. Sci. Technol. 2018, 52, 4331-4339. [CrossRef] [PubMed]

16. Mirbahai, L.; Chipman, J.K. Epigenetic memory of environmental organisms: A reflection of lifetime stressor exposures. Mutat Res. Toxicol. Environ. Mutagen. 2014, 764-765, 10-17. [CrossRef] [PubMed]

17. Jeremias, G.; Barbosa, J.; Marques, S.M.; De Schamphelaere, K.A.; Van Nieuwerburgh, F.; Deforce, D.; Gonçalves, F.J.; Pereira, J.L.; Asselman, J. Transgenerational Inheritance of DNA Hypomethylation in Daphnia magna in Response to Salinity Stress. Environ. Sci. Technol. 2018, 52, 10114-10123. [CrossRef] [PubMed]

18. Šrut, M. Ecotoxicological epigenetics in invertebrates: Emerging tool for the evaluation of present and past pollution burden. Chemosphere 2021, 282, 131026. [CrossRef]

19. Holliday, R. Epigenetics: A Historical Overview. Epigenetics 2006, 1, 76-80. [CrossRef]

20. Riggs, A.D. X inactivation, differentiation, and DNA methylation. Cytogenet Genome Res. 1975, 14, 9-25. [CrossRef]

21. Holliday, R.; Pugh, J.E. DNA Modification Mechanisms and Gene Activity During Development. Science 1975, 187, $226-232$. [CrossRef]

22. Moore, L.D.; Le, T.; Fan, G. DNA Methylation and Its Basic Function. Neuropsychopharmacology 2013, 38, 23-38. [CrossRef]

23. Okano, M.; Bell, D.W.; Haber, D.A.; Li, E. DNA Methyltransferases Dnmt3a and Dnmt3b Are Essential for De Novo Methylation and Mammalian Development. Cell 1999, 99, 247-257. [CrossRef]

24. Lyko, F. The DNA methyltransferase family: A versatile toolkit for epigenetic regulation. Nat. Rev. Genet. 2017, 19, 81-92. [CrossRef] [PubMed]

25. Sassa, A.; Kanemaru, Y.; Kamoshita, N.; Honma, M.; Yasui, M. Mutagenic consequences of cytosine alterations site-specifically embedded in the human genome. Genes Environ. 2016, 38, 17. [CrossRef] [PubMed]

26. Kagiwada, S.; Kurimoto, K.; Hirota, T.; Yamaji, M.; Saitou, M. Replication-coupled passive DNA demethylation for the erasure of genome imprints in mice. EMBO J. 2012, 32, 340-353. [CrossRef] [PubMed]

27. Rasmussen, K.D.; Helin, K. Role of TET enzymes in DNA methylation, development, and cancer. Genes Dev. 2016, 30, 733-750. [CrossRef] [PubMed]

28. Dahlet, T.; Lleida, A.A.; Al Adhami, H.; Dumas, M.; Bender, A.; Ngondo, R.P.; Tanguy, M.; Vallet, J.; Auclair, G.; Bardet, A.F.; et al. Genome-wide analysis in the mouse embryo reveals the importance of DNA methylation for transcription integrity. Nat. Commun. 2020, 11, 3153. [CrossRef]

29. Héberlé, É.; Bardet, A.F. Sensitivity of transcription factors to DNA methylation. Essays Biochem. 2019, 63, 727-741. [CrossRef]

30. Kulis, M.; Esteller, M. DNA Methylation and Cancer. Adv. Genet. 2010, 70, 27-56. [CrossRef]

31. Seelan, R.S.; Mukhopadhyay, P.; Pisano, M.M.; Greene, R.M. Effects of 5-aza-2'-deoxycytidine (decitabine) on gene expression. Drug Metab. Rev. 2017, 50, 193-207. [CrossRef]

32. Filì, C.; Candoni, A.; Zannier, M.E.; Olivieri, J.; Imbergamo, S.; Caizzi, M.; Nadali, G.; Di Bona, E.; Ermacora, A.; Gottardi, M.; et al. Efficacy and toxicity of Decitabine in patients with acute myeloid leukemia (AML): A multicenter real-world experience. Leuk. Res. 2019, 76, 33-38. [CrossRef] 
33. Kumar, S.; Kim, Y. An endoparasitoid wasp influences host DNA methylation. Sci. Rep. 2017, 7, 43287. [CrossRef]

34. Xu, G.; Zhang, J.; Lyu, H.; Song, Q.; Feng, Q.; Xiang, H.; Zheng, S. DNA methylation mediates BmDeaf1-regulated tissue- and stage-specific expression of BmCHSA-2b in the silkworm, Bombyx mori. Epigenet. Chromatin 2018, 11, 32. [CrossRef] [PubMed]

35. Planques, A.; Kerner, P.; Ferry, L.; Grunau, C.; Gazave, E.; Vervoort, M. DNA methylation atlas and machinery in the developing and regenerating annelid Platynereis dumerilii. BMC Biol. 2021, 19, 148. [CrossRef] [PubMed]

36. Bouchard, J.; Momparler, R.L. Incorporation of 5-aza-2'-deoxycytidine-5'-triphosphate into DNA. Interactions with mammalian DNA polymerase alpha and DNA methylase. Mol. Pharmacol. 1983, 24, 109-114.

37. Christman, J.K. 5-Azacytidine and 5-aza-2'-deoxycytidine as inhibitors of DNA methylation: Mechanistic studies and their implications for cancer therapy. Oncogene 2002, 21, 5483-5495. [CrossRef]

38. Momparler, R.L. Pharmacology of 5-aza-2'-deoxycytidine (decitabine). Semin. Hematol. 2005, 42, S9-S16. [CrossRef]

39. Creusot, F.; Acs, G.; Christman, J.K. Inhibition of DNA methyltransferase and induction of Friend erythroleukemia cell differentiation by 5-azacytidine and 5-aza-2'-deoxycytidine. J. Biol. Chem. 1982, 257, 2041-2048. [CrossRef]

40. Taylor, S.M.; Jones, P.A. Mechanism of action of eukaryotic DNA methyltransferase: Use of 5-azacytosine-containing DNA. J. Mol. Biol. 1982, 162, 679-692. [CrossRef]

41. Akcha, F.; Barranger, A.; Bachère, E. Genotoxic and epigenetic effects of diuron in the Pacific oyster: In vitro evidence of interaction between DNA damage and DNA methylation. Environ. Sci. Pollut. Res. 2020, 28, 8266-8280. [CrossRef]

42. Bachère, E.; Barranger, A.; Bruno, R.; Rouxel, J.; Menard, D.; Piquemal, D.; Akcha, F. Parental diuron-exposure alters offspring transcriptome and fitness in Pacific oyster Crassostrea gigas. Ecotoxicol. Environ. Saf. 2017, 142, 51-58. [CrossRef]

43. Gatzmann, F.; Falckenhayn, C.; Gutekunst, J.; Hanna, K.; Raddatz, G.; Carneiro, V.C.; Lyko, F. The methylome of the marbled crayfish links gene body methylation to stable expression of poorly accessible genes. Epigenet. Chromatin 2018, 11, 57. [CrossRef] [PubMed]

44. Šrut, M.; Drechsel, V.; Höckner, M. Low levels of Cd induce persisting epigenetic modifications and acclimation mechanisms in the earthworm Lumbricus terrestris. PLoS ONE 2017, 12, e0176047. [CrossRef] [PubMed]

45. Homa, J.; Klimek, M.; Kruk, J.; Cocquerelle, C.; Vandenbulcke, F.; Plytycz, B. Metal-specific effects on metallothionein gene induction and riboflavin content in coelomocytes of Allolobophora chlorotica. Ecotoxicol. Environ. Saf. 2010, 73, 1937-1943. [CrossRef] [PubMed]

46. Aigner, G.P.; Pittl, V.; Fiechtner, B.; Egger, B.; Šrut, M.; Höckner, M. Common mechanisms cannot explain time- and dosedependent DNA methylation changes in earthworms exposed to cadmium. Sci. Total Environ. 2021, 812, 151468. [CrossRef] [PubMed]

47. Jeremias, G.; Gonçalves, F.J.M.; Pereira, J.L.; Asselman, J. Prospects for incorporation of epigenetic biomarkers in human health and environmental risk assessment of chemicals. Biol. Rev. 2020, 95, 822-846. [CrossRef]

48. Vandegehuchte, M.B.; Janssen, C.R. Epigenetics in an ecotoxicological context. Mutat. Res. Toxicol. Environ. Mutagen. 2014, 764-765, 36-45. [CrossRef]

49. Drechsel, V.; Schauer, K.; Šrut, M.; Höckner, M. Regulatory Plasticity of Earthworm wMT-2 Gene Expression. Int. J. Mol. Sci. 2017, 18, 1113. [CrossRef]

50. Du Preez, P.H.; Breeds, K.; Burger, N.F.V.; Swiegers, H.W.; Truter, J.C.; Botha, A.-M. DNA Methylation and Demethylation Are Regulated by Functional DNA Methyltransferases and DnTET Enzymes in Diuraphis noxia. Front. Genet. 2020, 11, 452. [CrossRef]

51. R Core Team. R: A Language and Environment for Statistical Computing; R Foundation for Statistical Computing: Vienna, Austria, 2021; Available online: https:/ / www.R-project.org (accessed on 26 December 2021).

52. Oksanen, J.; Blanchet, F.G.; Friendly, M.; Kindt, R.; Legendre, P.; McGlinn, D.; Minchin, P.R.; O’Hara, R.B.; Simpson, G.L.; Solymos, P.; et al. Vegan: Community Ecology Package. 2019. Available online: https://cran.r-project.org/web/packages/ vegan/index.html (accessed on 26 December 2021).

53. Kang, S.W.; Madkour, M.; Kuenzel, W.J. Tissue-Specific Expression of DNA Methyltransferases Involved in Early-Life Nutritional Stress of Chicken, Gallus gallus. Front. Genet. 2017, 8, 204. [CrossRef]

54. Zupkovitz, G.; Kabiljo, J.; Kothmayer, M.; Schlick, K.; Schöfer, C.; Lagger, S.; Pusch, O. Analysis of Methylation Dynamics Reveals a Tissue-Specific, Age-Dependent Decline in 5-Methylcytosine Within the Genome of the Vertebrate Aging Model Nothobranchius furzeri. Front. Mol. Biosci. 2021, 8, 627143. [CrossRef]

55. Waalkes, M.P.; Miller, M.S.; Wilson, M.J.; Bare, R.M.; McDowell, A.E. Increased metallothionein gene expression in 5-aza-2'deoxycytidine-induced resistance to cadmium cytotoxicity. Chem. Interact. 1988, 66, 189-204. [CrossRef]

56. Amarasinghe, H.E.; Clayton, C.I.; Mallon, E.B. Methylation and worker reproduction in the bumblebee (Bombus terrestris). Proc. R. Soc. B Boil. Sci. 2014, 281, 20132502. [CrossRef] [PubMed]

57. Homa, J.; Bzowska, M.; Klimek, M.; Plytycz, B. Flow cytometric quantification of proliferating coelomocytes non-invasively retrieved from the earthworm, Dendrobaena veneta. Dev. Comp. Immunol. 2008, 32, 9-14. [CrossRef]

58. Cook, N.; Parker, D.J.; Tauber, E.; Pannebakker, B.A.; Shuker, D.M.; Dj, P.; Ba, P. Validating the Demethylating Effects of 5-aza-2'-deoxycytidine in Insects Requires a Whole-Genome Approach. Am. Nat. 2019, 194, 432-438. [CrossRef]

59. Yang, J.; Tian, X.; Yang, J.; Cui, J.; Jiang, S.; Shi, R.; Liu, Y.; Liu, X.; Xu, W.; Xie, W.; et al. 5-aza-2'-deoxycytidine, a DNA methylation inhibitor, induces cytotoxicity, cell cycle dynamics and alters expression of DNA methyltransferase 1 and 3A in mouse hippocampus-derived neuronal HT22 cells. J. Toxicol. Environ. Health Part A 2017, 80, 1222-1229. [CrossRef] 
60. Honeywell, R.J.; Sarkisjan, D.; Kristensen, M.H.; de Klerk, D.J.; Peters, G.J. DNA methyltransferases expression in normal tissues and various human cancer cell lines, xenografts and tumors. Nucleosides Nucleotides Nucleic Acids 2018, 37, 696-708. [CrossRef]

61. Honeywell, R.J.; Sarkisjan, D.; Kathmann, I.; Kristensen, M.H.; Peters, G.J. Sensitive liquid chromatography mass spectrometry (LC-MS) assay reveals novel insights on DNA methylation and incorporation of gemcitabine, its metabolite difluorodeoxyuridine, deoxyuridine, and RX-3117 into DNA. Nucleosides Nucleotides Nucleic Acids 2016, 35, 652-662. [CrossRef]

62. Chaney, R.L. Cadmium and Zinc. In Trace Elements in Soils; John Wiley \& Sons, Ltd.: Chichester, UK, 2010 ; pp. $409-439$.

63. Das, P.; Samantaray, S.; Rout, G.R. Studies on cadmium toxicity in plants: A review. Environ. Pollut. 1997, 98, 29-36. [CrossRef]

64. Tang, L.; Qiu, R.; Tang, Y.; Wang, S. Cadmium-zinc exchange and their binary relationship in the structure of Zn-related proteins: A mini review. Metallomics 2014, 6, 1313-1323. [CrossRef]

65. He, S.; Wang, F.; Yang, L.; Guo, C.; Wan, R.; Ke, A.; Xu, L.; Hu, G.; Xu, X.; Shen, J.; et al. Expression of DNMT1 and DNMT3a Are Regulated by GLI1 in Human Pancreatic Cancer. PLoS ONE 2011, 6, e27684. [CrossRef]

66. Kishikawa, S.; Murata, T.; Kimura, H.; Shiota, K.; Yokoyama, K.K. Regulation of transcription of the Dnmt1 gene by Sp1 and Sp3 zinc finger proteins. JBIC J. Biol. Inorg. Chem. 2002, 269, 2961-2970. [CrossRef] [PubMed]

67. Hodge, D.R.; Xiao, W.; Clausen, P.A.; Heidecker, G.; Szyf, M.; Farrar, W.L. Interleukin-6 Regulation of the Human DNA Methyltransferase (HDNMT) Gene in Human Erythroleukemia Cells. J. Biol. Chem. 2001, 276, 39508-39511. [CrossRef] [PubMed]

68. Ansari, M.; Khan, N.M.; Ahmad, N.; Green, J.; Novak, K.; Haqqi, T.M. Genetic Inactivation of ZCCHC 6 Suppresses Interleukin-6 Expression and Reduces the Severity of Experimental Osteoarthritis in Mice. Arthritis Rheumatol. 2019, 71, 583-593. [CrossRef] [PubMed]

69. Pestana, J.L.; Novais, S.C.; Norouzitallab, P.; Vandegehuchte, M.B.; Bossier, P.; De Schamphelaere, K.A. Non-lethal heat shock increases tolerance to metal exposure in brine shrimp. Environ. Res. 2016, 151, 663-670. [CrossRef] 